\title{
Clinicopathological and Prognostic Significance of Maspin Expression in Resected Non-Small Cell Lung Cancer: A Meta- Analysis
}

\section{Yan Wang}

Sichuan University West China Hospital

\section{Yi Wang}

Sichuan University West China Hospital

\section{Yingxian Dong}

Sichuan University West China Hospital

Jialong Li

Sichuan University West China Hospital

Guowei Che ( $\nabla$ hxxiongwai@126.com )

Sichuan University West China Hospital https://orcid.org/0000-0003-2187-6346

\section{Research}

Keywords: Maspin, Clinicopathological characteristics, Prognosis, Non-small cell lung cancer, Meta-analysis

Posted Date: June 12th, 2020

DOl: https://doi.org/10.21203/rs.3.rs-34644/v1

License: (1) This work is licensed under a Creative Commons Attribution 4.0 International License. Read Full License 


\section{Abstract}

Objective To explore the association of maspin expression with clinical pathological parameters and prognosis in non-small cell lung cancer (NSCLC) who received the surgical therapy.

Methods The EMBASE, Web of Science and PubMed were searched to identify eligible studies to 3 December, 2019. The correlation of maspin expression with clinicopathological characteristics and survival of resected NSCLC patients was assessed by the combined relative risk (RR) and hazard ratio (HR) with corresponding 95\% confidence interval (Cl), respectively. All statistical analyses were performed via the Stata 12.0 software.

Results A total of 12 articles involving 1771 patients were included. The results manifested that maspin was more prevalent in lung squamous cell carcinoma (SCC) (RR=0.36, 95\% Cl: 0.22-0.60, $P \otimes 0.001)$ and significantly associated with P53 expression ( $\mathrm{RR}=1.50,95 \% \mathrm{Cl}: 1.00-2.24, P=0.048)$, while no significant correlation of maspin with other clinicopathological parameters such as the gender, age, tumor size, lymph node metastasis, tumor node metastasis (TNM) stage or differentiation status was observed. As for the prognosis representing as overall survival (OS), disease-free survival (DFS) and cancer-specific survival (CSS), only significant association between maspin and CSS (HR=1.58, 95\% Cl: 1.16-2.15, $P=0.003$ ) was revealed. However, the subgroup analysis for OS based on the histology demonstrated that maspin expression was an unfavourable and favourable prognostic indicator in lung adenocarcinoma ( $\mathrm{HR}=3.36,95 \% \mathrm{Cl}: 1.44-7.87, P=0.005)$ and SCC (HR=0.44, 95\% Cl: 0.27-0.71, $P=0.001)$, respectively.

Conclusion Maspin expression was correlated with histology type and P53 expression, but no certain association of maspin with other clinicopathological characteristics or prognosis was observed in resected NSCLC. More well-designed prospective researches with big samples are still needed to further assess the clinicopathological and prognostic significance of maspin in NSCLC patients undergoing surgical resection.

\section{Introduction}

Despite the great advances in diagnosis and therapy strategies the prognosis of non-small cell lung cancer (NSCLC) remains poor, ever after the radical resection at an early stage [1,2]. Therefore, in recent years, lots of investigation about the molecular pathogenesis of NSCLC has been done and an increasing number of cancer-specific biomarkers which are correlated with progression and prognosis of NSCLC patients have been reported, such as the melanoma associated antigen-A (MAGE-A) and EGFR $[3,4]$.

Maspin, a member of the serine protease inhibitor (serpin) family, is a 42-kDa protein and shows strong structural homology with other members of this serpin super-family, such as the a1-antitrypsin, plasminogen activator inhibitors1 and 2 [5]. It was first discovered in normal mammary epithelial cells and later in breast carcinoma [6]. In breast cancer, maspin was reported as a tumor suppressor and down-regulation of maspin indicated worse clinical outcomes [7]. Furthermore, a few studies have explored its clinicopathological and prognostic significance in several malignancies such as the ovary carcinoma [8], pancreatic carcinoma [9] and also NSCLC [10]. Some articles demonstrated that the expression of maspin was a predictor for the limited development, metastasis and improved survival in resected NSCLC [10-12]. However, other studies reported a significant correlation between upregulation of maspin and malignant development and poor prognosis of NSCLC patients who received the surgical therapy [13-15].

Therefore, the current meta-analysis was performed to further determine the clinical significance of maspin expression in resected NSCLC and then contribute to the risk evaluation and therapy strategy formulation of NSCLC patients.

\section{Materials And Methods}

\section{Literature search}

A publication search was performed through EMBASE, Web of Science and PubMed databases updated on 3 December, 2019. The following terms were used: maspin, lung, pulmonary, cancer, tumor, carcinoma and neoplasm and the specific search 
strategy was: (lung OR pulmonary) AND (cancer OR tumor OR carcinoma OR neoplasm) AND maspin. Furthermore, the references cited in included articles were also reviewed for eligibility.

\section{Inclusion and exclusion criteria}

The following inclusion criteria were applied: 1) articles assessed the correlation of maspin expression with clinicopathological parameters and survival, especially with survival; 2) patients were diagnosed as NSCLC pathologically and received surgical resection; 3 ) articles directly reported the HRs with $95 \%$ Cls or provided enough information like the Kaplan-Meier curve to calculate them; 4) full texts were available; 5) if data were overlapped or duplicated, only the latest publication was included.

The exclusion criteria were as follows: 1) conference abstracts, letters, reviews, opinions, case reports and animal trials; 2) articles did not provide enough data to calculate HRs with $95 \%$ Cls when they were not directly reported.

The literature retrieval and selection were performed by two individual researchers (Yan Wang and Yi Wang) and all disagreements were resolved by team discussion.

\section{Data extraction and assessment of literature quality}

Necessary information was extracted from eligible articles by two authors (Yan Wang and Yi Wang) independently, including the name of first author, publication year, country, number of enrolled patients, gender, age, tumor size, lymph node metastasis status, tumor node metastasis (TNM stage), differentiation status, histology, P53 expression, number of patients with "positive maspin expression", definition of "positive maspin expression", detection method, endpoint events, HRs with corresponding $95 \%$ Cls.

The Newcastle Ottawa Scale (NOS) score was applied to assess the quality of included studies (http://www.ohri.ca/programs/clinical_epidemiology/oxford.htm) and articles which earned a score of 6 or higher were regarded as high-quality studies. Two reviewers (Yan Wang and Yi Wang) did this work independently and any disagreement was resolved through team discussion until a consensus reached.

\section{Statistical analysis}

We used the STATA 12.0 software to perform statistical analyses. The association of maspin expression with clinicopathological characteristics and prognosis in resected NSCLC were assessed by the pooled relative risks (RRs) and HRs with corresponding 95\% Cls, respectively. HRs with $95 \%$ Cls in multivariate models were used whenever available; and if the articles did not directly report them, they would be estimated from the Kaplan-Meier curves by the method described by Tierney et al. [16]. The Chi-square based Q-test and $R$ statistic were applied to assess the heterogeneity among included publications [17]. If significant heterogeneity representing as $P \otimes 0.10$ or/and $R^{2} \nabla 50 \%$ was observed, the random-effect modes was applied; otherwise the fixedeffect model was used [18]. The sensitivity analysis was performed to assess the stability of our results. The potential publication bias was detected with the Begg's funnel plot and Egger's test [19]. A $P$ value $₫ 0.05$ was regarded as statistical significance.

\section{Results}

\section{Literature selection process}

According to the established retrieval strategy, 223 records, after removing 136 duplicates, were evaluated for eligibility and 18 publications were reviewed with full texts (Fig. 1). Eventually, a total of 12 articles [10-15, 20-25] were included into our analysis.

\section{Basic characteristics of included studies}


Most of included studies (10/12) were from Asian countries, China and Japan, and used the immunohistochemistry method to detect maspin expression. The sample size and proportion of patients with positive maspin expression ranged from 55 to 352 and from $25-68 \%$. All publications were high-quality studies with a NOS score of 6 or higher. Detailed information was shown in Table 1. 
Table 1

Basic characteristics of included studies.

\begin{tabular}{|c|c|c|c|c|c|c|c|c|c|c|}
\hline Author & Year & Country & $\begin{array}{l}\text { Sample } \\
\text { size }\end{array}$ & $\begin{array}{l}\text { Positive, } \\
\text { n (\%) }\end{array}$ & $\begin{array}{l}\text { TNM } \\
\text { stage }\end{array}$ & $\begin{array}{l}\text { Definition } \\
\text { of positive } \\
\text { "maspin } \\
\text { expression" }\end{array}$ & $\begin{array}{l}\text { Detection } \\
\text { method }\end{array}$ & Endpoint & $\begin{array}{l}\text { Source } \\
\text { of HR }\end{array}$ & $\begin{array}{l}\text { NOS } \\
\text { score }\end{array}$ \\
\hline Hirai [21] & 2005 & Japan & 132 & $73(55)$ & $\nabla-\rrbracket$ & $\begin{array}{l}\text { Maspin } \\
\text { presence in } \\
₫ 40 \% \\
\text { cancer } \\
\text { cells }\end{array}$ & $\mathrm{IHC}$ & OS & $\mathrm{R}$ & 8 \\
\hline $\begin{array}{l}\text { Katakura } \\
{[11]}\end{array}$ & 2006 & Japan & 55 & $26(68)$ & 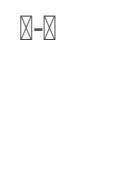 & $\begin{array}{l}\text { Median } \\
\text { maspin } \\
\text { mRNA } \\
\text { value } \\
(2.57)\end{array}$ & RT-PCR & OS & $\mathrm{R}$ & 7 \\
\hline $\begin{array}{l}\text { Woenckhaus } \\
\text { [22] }\end{array}$ & 2006 & Germany & 352 & 133(38) & NR & $\begin{array}{l}\text { Maspin } \\
\text { presence in } \\
\otimes 10 \% \\
\text { cancer } \\
\text { cells }\end{array}$ & $\mathrm{IHC}$ & CSS & $\mathrm{E}$ & 7 \\
\hline $\begin{array}{l}\text { Nakagawa } \\
{[23]}\end{array}$ & 2006 & Japan & 210 & $73(35)$ & $\nabla-\otimes A$ & $+/++$ & $\mathrm{IHC}$ & OS & $\mathrm{R}$ & 7 \\
\hline $\begin{array}{l}\text { Takanami } \\
\text { [12] }\end{array}$ & 2008 & Japan & 181 & $74(41)$ & $\nabla-\bigotimes$ & $\begin{array}{l}\text { Maspin } \\
\text { presence in } \\
\bigotimes 5 \% \text { cancer } \\
\text { cells }\end{array}$ & $\mathrm{IHC}$ & OS/PFS & $\mathrm{R}$ & 7 \\
\hline Wu [13] & 2012 & China & 160 & $77(48)$ & $\nabla-\rrbracket$ & $\begin{array}{l}\text { Intensity } \\
\text { score with } \\
\text { percentage } \\
\text { score } \otimes 1\end{array}$ & $\mathrm{IHC}$ & OS & $\mathrm{R}$ & 6 \\
\hline Takagi [14] & 2014 & Japan & 110 & $27(25)$ & $\nabla-\otimes A$ & $\begin{array}{l}\text { Maspin } \\
\text { presence in } \\
\otimes 10 \% \\
\text { cancer } \\
\text { cells }\end{array}$ & $\mathrm{IHC}$ & OS/DFS & $\mathrm{R}$ & 7 \\
\hline Wang [24] & 2014 & China & 98 & $26(27)$ & NR & ++ & $\mathrm{IHC}$ & OS/DFS & $E$ & 8 \\
\hline $\begin{array}{l}\text { Matsuoka } \\
\text { [15] }\end{array}$ & 2015 & Japan & 101 & $25(25)$ & $\nabla-\nabla A$ & $\begin{array}{l}\text { Maspin } \\
\text { presence in } \\
₫ 10 \% \\
\text { cancer } \\
\text { cells }\end{array}$ & $\mathrm{IHC}$ & DFS/CSS & $\mathrm{R}$ & 7 \\
\hline Yaman [25] & 2015 & Turkey & 80 & $26(32)$ & $\nabla-\square$ & $\begin{array}{l}\text { Maspin } \\
\text { presence in } \\
\bigotimes 5 \% \text { cancer } \\
\text { cells }\end{array}$ & $\mathrm{IHC}$ & OS & $\mathrm{E}$ & 7 \\
\hline Lu [16] & 2016 & China & 111 & $59(53)$ & $\nabla-\rrbracket$ & NR & QT-PCR & DFS & $\mathrm{R}$ & 8 \\
\hline Ohno [26] & 2018 & Japan & 181 & $45(25)$ & $\nabla A$ & $\begin{array}{l}\text { Maspin } \\
\text { presence in } \\
\bigotimes 10 \% \\
\text { cancer } \\
\text { cells }\end{array}$ & $\mathrm{IHC}$ & DFS/CSS & $\mathrm{R}$ & 8 \\
\hline
\end{tabular}




\section{Association between maspin expression and clinicopathological characteristics in resected NSCLC}

We assessed the correlation of maspin with gender, age, tumor size, lymph node metastasis status, TNM stage, differentiation status, histology type and P53 expression based on available data. Our results manifested that maspin expression was more frequently observed in squamous cell carcinoma (SCC) than in adenocarcinoma (AC) (RR $=0.36,95 \% \mathrm{Cl}: 0.22-0.60, P \otimes 0.001)$ and significantly associated with $\mathrm{P} 53$ expression $(\mathrm{RR}=1.50,95 \% \mathrm{Cl}: 1.00-2.24, P=0.048)$. No significant relation of maspin with gender, age, tumor size, lymph node metastasis status, TNM stage or differentiation status was manifested in out meta-analysis. (Table 2) 
Table 2

Association between maspin expression and clinicopathological characteristics in non-small cell lung cancer.

\begin{tabular}{|c|c|c|c|c|c|c|c|c|}
\hline Author & $\begin{array}{l}\text { Gender } \\
\text { (M vs } \\
\text { F) }\end{array}$ & $\begin{array}{l}\text { Age }(\geq \\
60 \text { vs } \\
\square 60)\end{array}$ & $\begin{array}{l}\text { Tumor } \\
\text { size }(T 3,4 \\
\text { vs T1,2) }\end{array}$ & $\begin{array}{l}\text { Lymph node } \\
\text { metastasis } \\
(\mathrm{N}+\mathrm{vs}-)\end{array}$ & $\begin{array}{l}\text { TNM } \\
(\bigotimes, \bigotimes \\
\text { vs凹,囚) }\end{array}$ & $\begin{array}{l}\text { Differentiation } \\
\text { (poor vs } \\
\text { moderate or } \\
\text { well) }\end{array}$ & $\begin{array}{l}\text { Histology } \\
\text { (AC vs } \\
\text { SCC) }\end{array}$ & $\begin{array}{l}\text { P53 } \\
\text { expression } \\
\text { (+ vs -) }\end{array}$ \\
\hline Hirai [21] & $\begin{array}{l}1.156 \\
(0.814- \\
1.640)\end{array}$ & - & - & $\begin{array}{l}1.206 \\
(0.883- \\
1.647)\end{array}$ & $\begin{array}{l}1.957 \\
(1.438- \\
2.663)\end{array}$ & $\begin{array}{l}0.765(0.487- \\
1.202)\end{array}$ & $\begin{array}{l}0.879 \\
(0.639- \\
1.209)\end{array}$ & $\begin{array}{l}1.986 \\
(1.329- \\
2.968)\end{array}$ \\
\hline $\begin{array}{l}\text { Katakura } \\
{[11]}\end{array}$ & - & - & - & - & - & - & - & - \\
\hline $\begin{array}{l}\text { Woenckhaus } \\
\text { [22] }\end{array}$ & - & - & $\begin{array}{l}1.311 \\
(0.946- \\
1.817)\end{array}$ & $\begin{array}{l}0.993 \\
(0.772- \\
1.278)\end{array}$ & - & - & $\begin{array}{l}0.244 \\
(0.131- \\
0.458)\end{array}$ & $\begin{array}{l}1.060 \\
(0.811- \\
1.384)\end{array}$ \\
\hline $\begin{array}{l}\text { Nakagawa } \\
{[23]}\end{array}$ & $\begin{array}{l}2.202 \\
(1.250- \\
3.880)\end{array}$ & - & - & - & $\begin{array}{l}0.867 \\
(0.571- \\
1.315)\end{array}$ & $\begin{array}{l}0.933(0.600- \\
1.452)\end{array}$ & $\begin{array}{l}0.152 \\
(0.090- \\
0.258)\end{array}$ & $\begin{array}{l}1.708 \\
(1.177- \\
2.480)\end{array}$ \\
\hline $\begin{array}{l}\text { Takanami } \\
{[12]}\end{array}$ & $\begin{array}{l}2.207 \\
(1.197- \\
3.432)\end{array}$ & - & $\begin{array}{l}1.172 \\
(0.807- \\
1.703)\end{array}$ & $\begin{array}{l}0.988 \\
(0.688- \\
1.418)\end{array}$ & $\begin{array}{l}1.100 \\
(0.760- \\
1.591)\end{array}$ & - & $\begin{array}{l}0.348 \\
(0.235- \\
0.514)\end{array}$ & - \\
\hline Wu [13] & $\begin{array}{l}0.954 \\
(0.639- \\
1.424)\end{array}$ & $\begin{array}{l}0.8883 \\
(0.641- \\
1.217)\end{array}$ & - & $\begin{array}{l}0.632 \\
(0.447- \\
0.892)\end{array}$ & $\begin{array}{l}0.390 \\
(0.269- \\
0.563)\end{array}$ & $\begin{array}{l}0.765(0.491- \\
1.194)\end{array}$ & $\begin{array}{l}0.586 \\
(0.369- \\
0.931)\end{array}$ & - \\
\hline Takagi [14] & $\begin{array}{l}1.455 \\
(0.744- \\
2.844)\end{array}$ & - & - & $\begin{array}{l}2.858 \\
(1.541- \\
5.301)\end{array}$ & $\begin{array}{l}3.206 \\
(1.762- \\
5.834)\end{array}$ & - & - & - \\
\hline Wang [24] & $\begin{array}{l}1.196 \\
(0.595- \\
2.405)\end{array}$ & $\begin{array}{l}0.951 \\
(0.491- \\
1.840)\end{array}$ & & $\begin{array}{l}0.182 \\
(0.068- \\
0.489)\end{array}$ & & $\begin{array}{l}1.492(0.771- \\
2.887)\end{array}$ & $\begin{array}{l}0.421 \\
(0.214- \\
0.829)\end{array}$ & - \\
\hline $\begin{array}{l}\text { Matsuoka } \\
{[15]}\end{array}$ & $\begin{array}{l}0.717 \\
(0.266- \\
1.937)\end{array}$ & - & - & $\begin{array}{l}2.521 \\
(1.325- \\
4.796)\end{array}$ & $\begin{array}{l}2.045 \\
(0.962- \\
4.347)\end{array}$ & $\begin{array}{l}1.433(0.636- \\
3.229)\end{array}$ & - & - \\
\hline Yaman [25] & - & - & - & - & - & - & $\begin{array}{l}0.261 \\
(0.131- \\
0.520)\end{array}$ & - \\
\hline Lu [16] & $\begin{array}{l}1.029 \\
(0.725- \\
1.461)\end{array}$ & $\begin{array}{l}1.026 \\
(0.710- \\
1.481)\end{array}$ & $\begin{array}{l}0.735 \\
(0.337- \\
1.602)\end{array}$ & $\begin{array}{l}0.784 \\
(0.549- \\
1.121)\end{array}$ & $\begin{array}{l}0.744 \\
(0.491- \\
1.129)\end{array}$ & - & - & - \\
\hline Ohno [26] & $\begin{array}{l}1.351 \\
(0.811- \\
2.250)\end{array}$ & - & - & $\begin{array}{l}2.211 \\
(1.358- \\
3.599)\end{array}$ & - & $\begin{array}{l}2.628(1.614- \\
4.280)\end{array}$ & - & - \\
\hline Overall & $\begin{array}{l}1.25 \\
(1.06- \\
1.46)\end{array}$ & $\begin{array}{l}0.95 \\
(0.75- \\
1.19)\end{array}$ & $\begin{array}{l}1.19 \\
(0.94- \\
1.50)\end{array}$ & $\begin{array}{l}1.11(0.78- \\
1.56)\end{array}$ & $\begin{array}{l}1.17 \\
(0.69- \\
1.96)\end{array}$ & $1.18(0.78-1.79)$ & $\begin{array}{l}0.36 \\
(0.22- \\
0.60)\end{array}$ & $\begin{array}{l}1.50(1.00- \\
2.24)\end{array}$ \\
\hline
\end{tabular}

\section{Association between maspin expression and prognosis in resected NSCLC}

The results demonstrated that maspin expression was not significantly associated with overall survival (OS) $(\mathrm{HR}=0.86,95 \% \mathrm{Cl}$ : $0.42-1.76, P=0.671$ ) (Fig. 2) or disease-free survival (DFS) (HR=1.51, 95\% Cl: 0.96-2.38, $P=0.077$ ) (Fig. 3), but the significant correlation between maspin and cancer-specific survival (CSS) (HR $=1.58,95 \% \mathrm{Cl}$ : $1.16-2.15, P=0.003)$ was observed (Fig. 4). 
We also conducted the subgroup analysis based on the histology type, which demonstrated that maspin expression was an unfavourable and favourable prognostic indicator in lung adenocarcinoma ( $\mathrm{HR}=3.36,95 \% \mathrm{Cl}: 1.44-7.87, P=0.005)$ and SCC (HR $=0.44,95 \% \mathrm{Cl}: 0.27-0.71, P=0.001)$, respectively. (Table 3)

Table 3

Meta-analyses for the association of maspin expression with survival of resected non-small cell lung cancer patients.

\begin{tabular}{|c|c|c|c|c|c|}
\hline & No. of studies & HR & $95 \% \mathrm{Cl}$ & $P$ value & $\begin{array}{l}\text { Heterogeneity } \\
(P, P(\%))\end{array}$ \\
\hline Overall survival & 8 & 0.86 & $0.42-1.76$ & 0.671 & $\llbracket 0.001,80.8$ \\
\hline Histology & 4 & 0.70 & $0.23-2.16$ & 0.539 & $0.001,82.6$ \\
\hline Non-small cell lung cancer & 2 & 0.44 & $0.27-0.71$ & 0.001 & $0.717,0.0$ \\
\hline $\begin{array}{l}\text { Squamous cell carcinoma } \\
\text { Adenocarcinoma }\end{array}$ & 2 & 3.36 & $1.44-7.87$ & 0.005 & $0.582,0.0$ \\
\hline Disease-free survival & 6 & 1.51 & $0.96-2.38$ & 0.077 & $0.006,69.5$ \\
\hline Cancer-specific survival & 3 & 1.58 & $1.16-2.15$ & 0.003 & $0.473,0.0$ \\
\hline
\end{tabular}

\section{Sensitivity analysis}

To evaluate the stability of our pooled results, we conducted the sensitivity analysis by excluding single study each time and it indicated that our results were stable. (Fig. 5)

\section{Publication bias}

The Begg's funnel plot was not asymmetrical $(P=0.108)$ and the $P$ value of Egger's test was 0.057 , which indicated that no significant publication bias existed (Fig. 6).

\section{Discussion}

After combining relevant studies explored the association of maspin expression with clinical pathological characteristics and survival in resected NSCLC. The results indicated that maspin was more prevalent in lung SCC and significantly correlated with P53 expression. Unfortunately, no certain relation between maspin and prognosis was observed based on the current metaanalysis.

The results of previous studies about the clinical significance of maspin were highly controversial. A few studies demonstrated that maspin could serve as an inhibitor of angiogenesis and contributed to improved prognosis [26, 27]. It can act directly on endothelial cells by suppressing their migration to vascular endothelial growth factor (VEGFs) and basic fibroblast growth factors and then inhibit tumor angiogenesis [26]. Besides, Wu et al [12] demonstrated that vasculogenic mimicry (VM), an angiogenesisindependent pathway, was an independent prognostic factor and maspin expression was negatively associated with VM. However, some studies reported that maspin displayed an adverse influence on the tumor development and was a predictor for unfavourable prognosis in NSCLC [13-15]. TP53 was proven to be significantly associated with maspin expression [20, 22] and Zou et al [28] manifested that TP53 could activate maspin by directly binding to TP53 consensus-binding site of maspin promoter. In other words, maspin may be one of the TP53-targeted genes which involved in the process of cancer invasion and metastasis [28]. Thus, maspin might play a complex role in the process of tumorigenesis and progression in NSCLC patients. 
There are several possible reasons for this phenomenon. Goulet et al [29] reported that nuclear maspin expression in tumor cells contributed to its tumor suppressor activity. However, Takagi et al [13] manifested that cytoplasmic accumulation was an unfavourable prognostic factor of NSCLC patients, although the exact molecular mechanisms are unclear, and Takanami et al [10] found that cytoplasmic plus nuclear maspin expression was an independent favourable prognostic indicator in lung SCC. Therefore, cytoplasmic and nuclear expression of maspin may exhibit very different biological characteristics. Besides, the subgroup analysis for OS based on the histology proved that maspin expression was an unfavourable and favourable prognostic indicator in lung adenocarcinoma $(\mathrm{HR}=3.36,95 \% \mathrm{Cl}: 1.44-7.87, P=0.005)$ and SCC (HR= 0.44, 95\% Cl: $0.27-0.71, P=0.001)$, respectively, which indicated that maspin might also play a totally different role in different histological subtypes. Our metaanalysis demonstrated that maspin expression was much more prevalent in lung SCC than in AC, which may lead to the inaccuracy of the results of studies that did not perform subgroup analyses based on histology type.

In addition to what was mentioned above, there are still many fields about maspin expression in NSCLC that deserve further investigation. A few publications reported the significant correlation between maspin expression and TNM stage in NSCLC [12, $13,20]$, although we did not get a positive result. Thus, we still need to further investigated the influence caused by maspin on tumor development. It is well known that P53 mutation was significantly related with smoking [30] and maspin was shown as significant association with P53 expression; however, few included studies explored the influence of smoking on maspin expression. Besides, few studies conducted subgroup analyses stratified by the TNM stage which was an important prognostic factor and we suspected that maspin may show very different prognostic significance in patients with different TNM stage.

Although we were not able to draw a very certain conclusion about the prognostic value of maspin in resected NSCLC, we revealed the current advance and provided some valuable research directions about maspin expression in NSCLC. We expect that the current meta-analysis could help with the formulation of study program and interpretation of results in future investigation.

There are some limitations that should be addressed. First of all, all included studies are retrospective with relatively small samples. Second, due to lack of original data, we were unable to conduct subgroup analyses stratified by age, TNM stage, smoking status and et al. Third, significant heterogeneity among included studies was observed in our meta-analysis;

unfortunately, we failed to determine the source of heterogeneity. Four, the cut-off thresholds for the definition of positive maspin expression were different among included studies and we could not confirm the optimal one based on current information.

\section{Conclusions}

In conclusion, we demonstrated that maspin expression was correlated with histology type and P53 expression, but no certain correlation of maspin with other clinicopathological characteristics or prognosis was observed in resected NSCLC. More welldesigned prospective researches with big samples are urgently needed to further assess the clinicopathological and prognostic significance of maspin in NSCLC patients undergoing surgical resection.

\section{Abbreviations}

NSCLC: Non-small cell lung cancer; HR: Hazard ratio; Cl: Confidence interval; RR: Relative risk; SCC: Squamous cell carcinoma; TNM: Tumor-node-metastasis; OS: Overall survival; DFS: Disease-free survival; CSS: Cancer-specific survival; MAGE-A: melanoma associated antigen-A; AC: adenocarcinoma; IHC: Immunohistochemistry; RT-PCR: Reverse transcription polymerase chain reaction; NOS: Newcastle-Ottawa scale; VEGFs: vascular endothelial growth factor; VM: vasculogenic mimicry.

\section{Declarations}

\section{Acknowledgements}

Not applicable

\section{Authors' contributions}


GWC conceived and designed the analyses. YW and YW performed the literature search and selection, collected data and wrote the paper. YXD and JLL performed statistical analyses. All authors contributed substantially to its revision.

\section{Funding}

Not applicable

\section{Availability of data and materials}

All data are fully available without restriction.

\section{Ethics approval and consent to participate}

This paper did not use the experimental data from human subjects.

\section{Consent for publication}

Not applicable.

\section{Competing interests}

The authors declare that they have no competing interests

\section{References}

1. Asamura H, Goya T, Koshiishi $Y$ et al. A Japanese lung cancer registry study: prognosis of 13,010 resected lung cancers. J. Thorac. Oncol. 2008; 3; 46-52.

2. Kelsey $\mathrm{CR}$, Higgins KA, Peterson BL et al. Local recurrence after surgery for non-small cell lung cancer: a recursive partitioning analysis of multi-institutional data. J. Thorac. Cardiovasc.Surg. 2013; 146; 768-773

3. Zhang S, Zhai X, Wang G, et al. High expression of MAGE-A9 in tumor and stromal cells of non-small cell lung cancer was correlated with patient poor survival. Int J Clin Exp Pathol. 2015 1;8(1):541-50.

4. Fan G, Zhang K, Ding J, et al. Prognostic value of EGFR and KRAS in circulating tumor DNA in patients with advanced nonsmall cell lung cancer: a systematic review and meta-analysis. Oncotarget. 2017, 16;8(20):33922-33932.

5. Zou Z, Anisowicz A, Hendrix MJ, et al. Maspin, a serpin with tumor-suppressing activity in human mammary epithelial cells. Science 1994; 263:526-9.

6. Pemberton PA, Tripton AR, Pavloff MC. Maspin is an intracellular serpine that partitions into secretary vesicles and in present at the cell surface. J Histochem Cytochem 1997; 45:1697-706.

7. Umekita Y, Ohi Y, Sagaya Y, et al. Expression of maspin predicts poor prognosis in breast-cancer patients. Int J Cancer. 2002; 100:452-5.

8. Sood AK, Fletcher MS, Gruman LM, et al. The paradoxical expression of maspin in ovarian carcinoma. Clin Cancer Res. 2002; 8:2924-32.

9. Maass $\mathrm{N}$, Hojo T, Ueding M, et al. Expression of the tumor suppressor gene Maspin in human pancreatic cancers. Clin Cancer Res. 2001; 7:812-7.

10. Takanami I, Abiko T, Koizumi S, et al. Expression of Maspin in Non-Small-Cell Lung Cancer: Correlation with Clinical Features. Clin Lung Cancer. 2008 Nov;9(6):361-6. 
11. Katakura $\mathrm{H}$, Takenaka $\mathrm{K}$, Nakagawa $\mathrm{M}$, et al. Maspin gene expression is a significant prognostic factor in resected non-small cell lung cancer (NSCLC). Maspin in NSCLC. Lung Cancer. 2006 Mar;51(3):323-8.

12. Wu S, Yu L, Cheng Z, et al. Expression of maspin in non-small cell lung cancer and its relationship to vasculogenic mimicry. $J$ Huazhong Univ Sci Technolog Med Sci. 2012 Jun;32(3):346-352.

13. Takagi Y, Matsuoka Y, Shiomi T, et al. Cytoplasmic maspin expression is a predictor of poor prognosis in patients with lung adenocarcinoma measuring <3 cm. Histopathology. 2015 Apr;66(5):732-9.

14. Matsuoka Y, Takagi Y, Nosaka K, et al. Cytoplasmic expression of maspin predicts unfavourable prognosis in patients with squamous cell carcinoma of the lung. Histopathology. $2016 \mathrm{Jul} ; 69(1): 114-20$.

15. Lu M, Li J, Huang Z, et al. Aberrant Maspin mRNA Expression is Associated with Clinical Outcome in Patients with Pulmonary Adenocarcinoma. Med Sci Monit. 2016 Jan 13;22:134-9.

16. Vansteenkiste JF, Cho BC, Vanakesa T, et al. Efficacy of the MAGE-A3 cancer immunotherapeutic as adjuvant therapy in patients with resected MAGE-A3-positive non-small-cell lung cancer (MAGRIT): a randomised, double-blind, placebocontrolled, phase 3 trial. Lancet Oncol. 2016 Jun;17(6):822-835.

17. Stang A. Critical evaluation of the Newcastle-Ottawa scale for the assessment of the quality of nonrandomized studies in meta-analyses. Eurjepidemiol.2010; 25:603-605.

18. Tierney JF, Stewart LA, Ghersi D, et al. Practical methods for incorporating summary time-to-event data into meta-analysis. Trials. 2007 Jun 7;8:16.

19. Lau J, loannidis JP, Schmid CH. Quantitative synthesis in systematic reviews. Ann Intern Med. 1997 Nov 1;127(9):820-6.

20. Hirai K, Koizumi K, Haraguchi S, et al. Prognostic significance of the tumor suppressor gene maspin in non-small cell lung cancer. Ann Thorac Surg. 2005 Jan;79(1):248-53.

21. Woenckhaus M, Bubendorf L, Dalquen P, et al. Nuclear and cytoplasmic Maspin expression in primary non-small cell lung cancer. J Clin Pathol. 2007 May;60(5):483-6.

22. Nakagawa $M$, Katakura $H$, Adachi $M$, et al. Maspin expression and its clinical significance in non-small cell lung cancer. Ann Surg Oncol. 2006 Nov;13(11):1517-23.

23. Wang X, Wang Y, Li S, et al. Decreased maspin combined with elevated vascular endothelial growth factor $C$ is associated with poor prognosis in non-small cell lung cancer. Thorac Cancer. 2014 Sep;5(5):383-90.

24. Yaman B, Nart D, Ekren PK, et al. Expression of p63, TTF-1 and Maspin in Non-Small Cell Lung Carcinoma and Their Effect on the Prognosis and Differential Diagnosis. Turk Patoloji Derg. 2015;31(3):163-74.

25. Ohno T, Kubouchi Y, Wakahara M, et al. Clinical Significance of Subcellular Localization of Maspin in Patients with Pathological Stage IA Lung Adenocarcinoma. Anticancer Res. 2018 May;38(5):3001-3007.

26. Zhang M, Volpert O, Shi YH, et al. Maspin is an angiogenesis inhibitor. Nat Med 2000; 6:196-9.

27. Friedrich MG, Toma MI, Petri S, et al. Expression of maspin in non-muscle invasive bladder carcinoma: correlation with tumor angiogenesis and prognosis. Eur Urol 2004; 45:737-43.

28. Zou Z, Gao C, Nagaich AK, et al. p53 regulates the expression of the tumor suppressor gene maspin. J Biol Chem. 2000,275:6051-4.

29. Goulet B, Kennette W, Ablack A et al. Nuclear localization of maspin is essential for its inhibition of tumour growth and metastasis. Lab. Invest. 2011; 91; 1181-1187.

30. Wu XC, Zheng YF, Tang M, et al. Association Between Smoking and p53 Mutation in Oesophageal Squamous Cell Carcinoma: A Meta-analysis. Clin Oncol (R Coll Radiol). 2015 Jun;27(6):337-44.

\section{Figures}




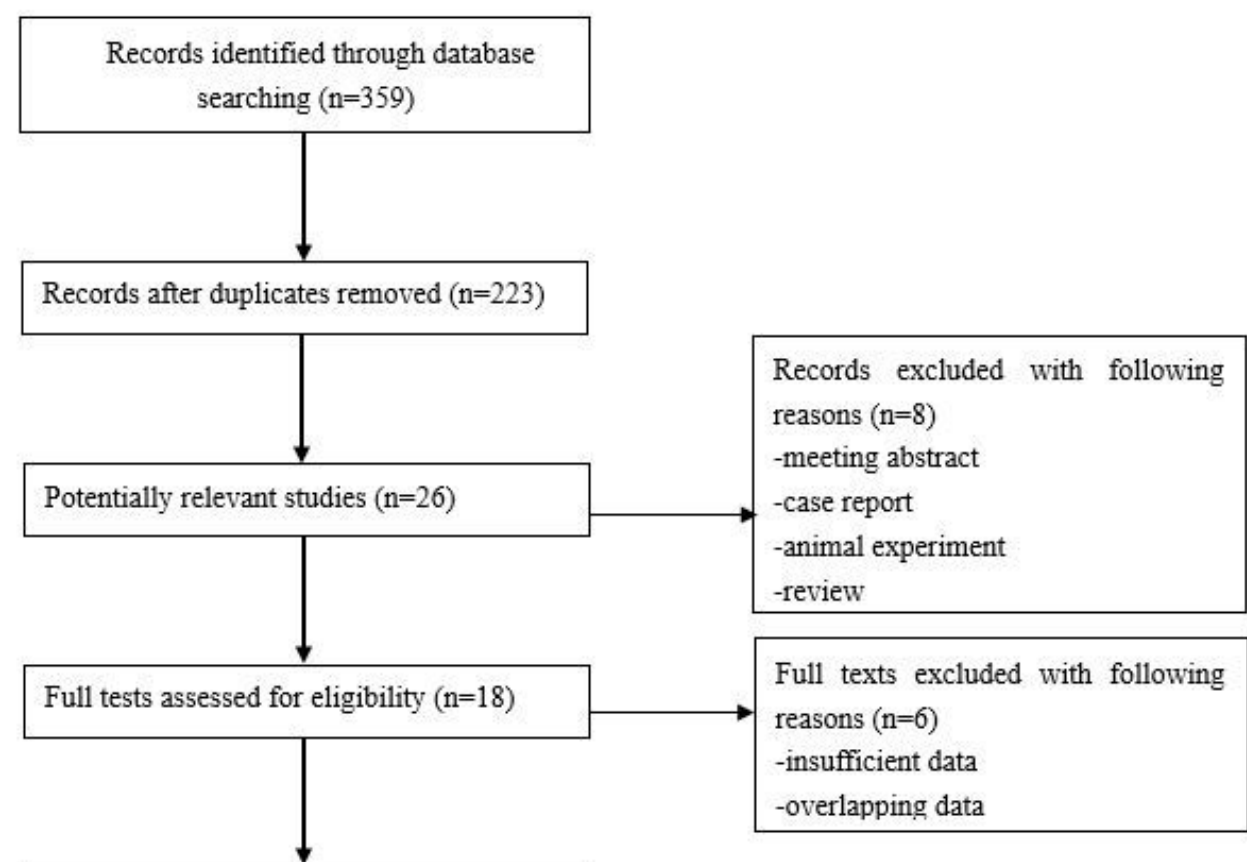

Studies included in meta-analysis $(\mathrm{n}=12)$

\section{Figure 1}

The flow diagram of this meta-analysis. 
ID

HR $(95 \% \mathrm{Cl})$

Weight

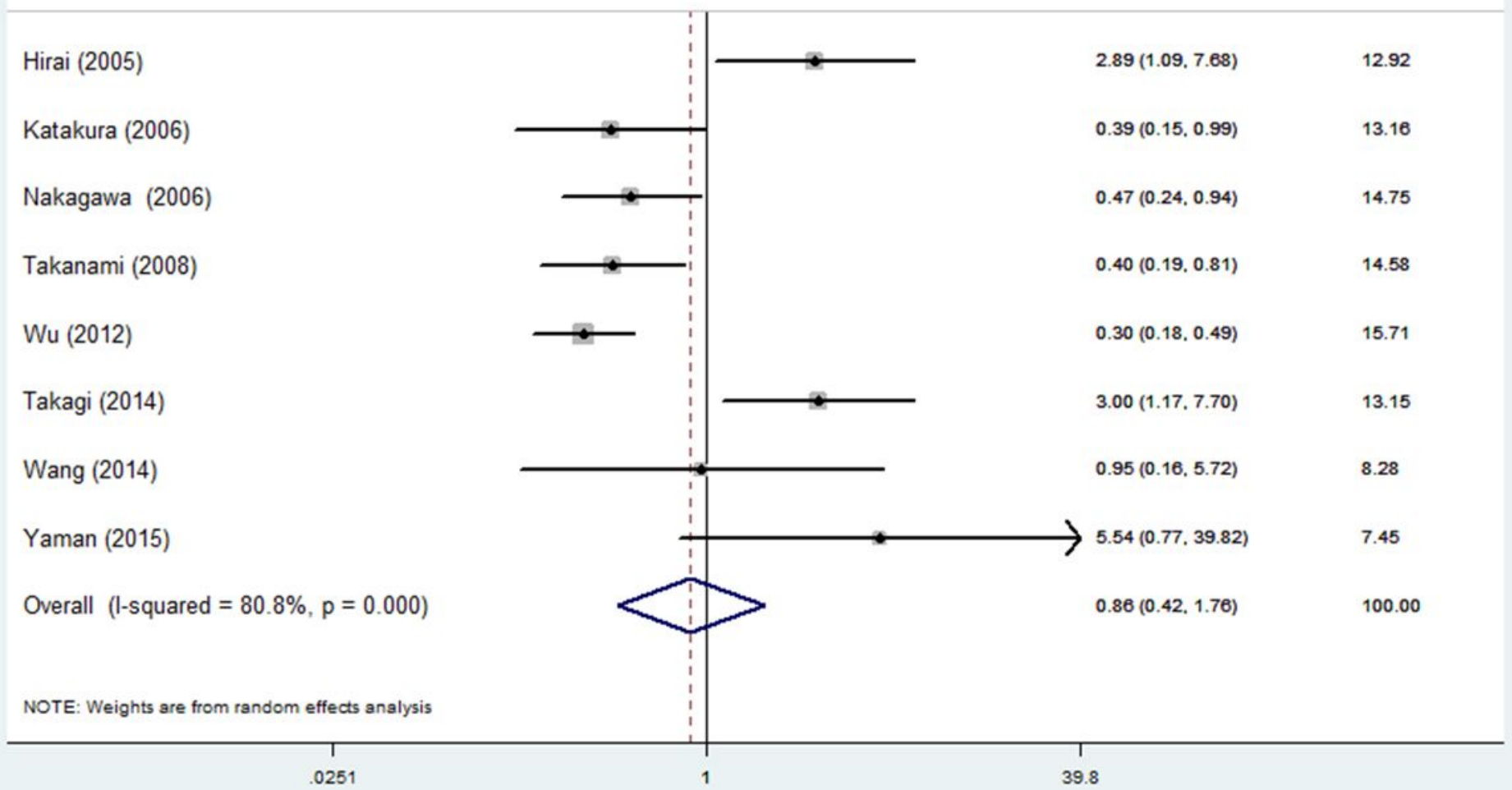

Figure 2

Forest plot of the association between maspin and overall survival. 
ID

$\mathrm{HR}(95 \% \mathrm{Cl})$

Weight

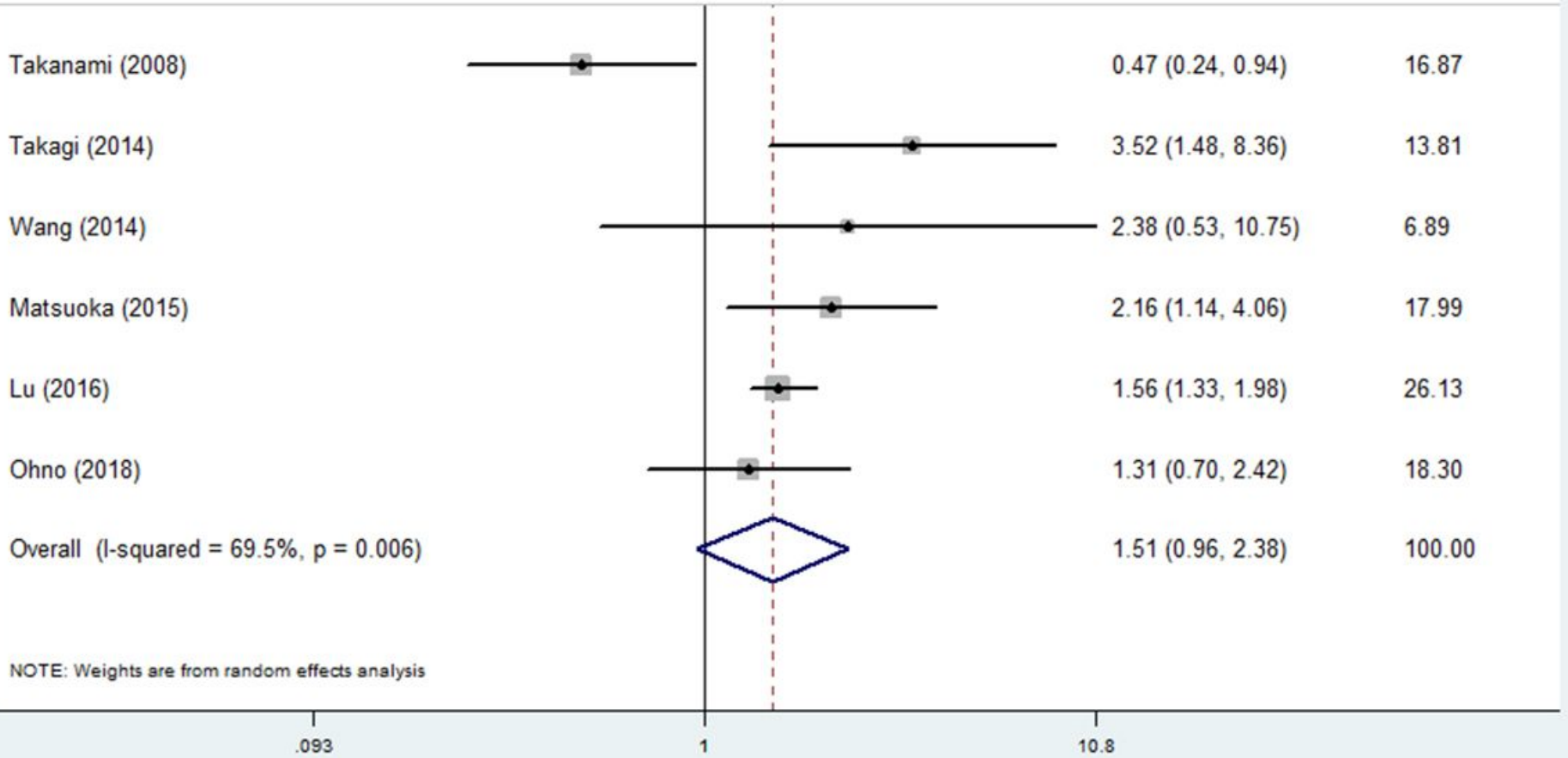

Figure 3

Forest plot of the association between maspin and disease-free survival. 
ID

HR $(95 \% \mathrm{Cl})$

Weight

Woenckhaus (2006)

Matsuoka (2015)

Ohno (2018)

Overall $(\mathrm{I}$-squared $=0.0 \%, p=0.473$ )
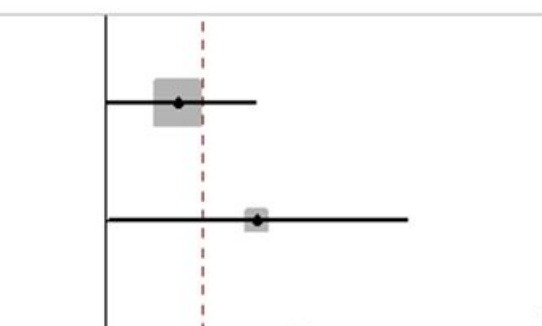

$1.42(1.00,2.03) \quad 74.72$

$2.04(1.01,4.13) \quad 18.89$

$2.58(0.77,8.67) \quad 6.39$

$1.58(1.16,2.15) \quad 100.00$

Figure 4

Forest plot of the association between maspin and cancer-specific survival. 
Begg's funnel plot with pseudo 95\% confidence limits

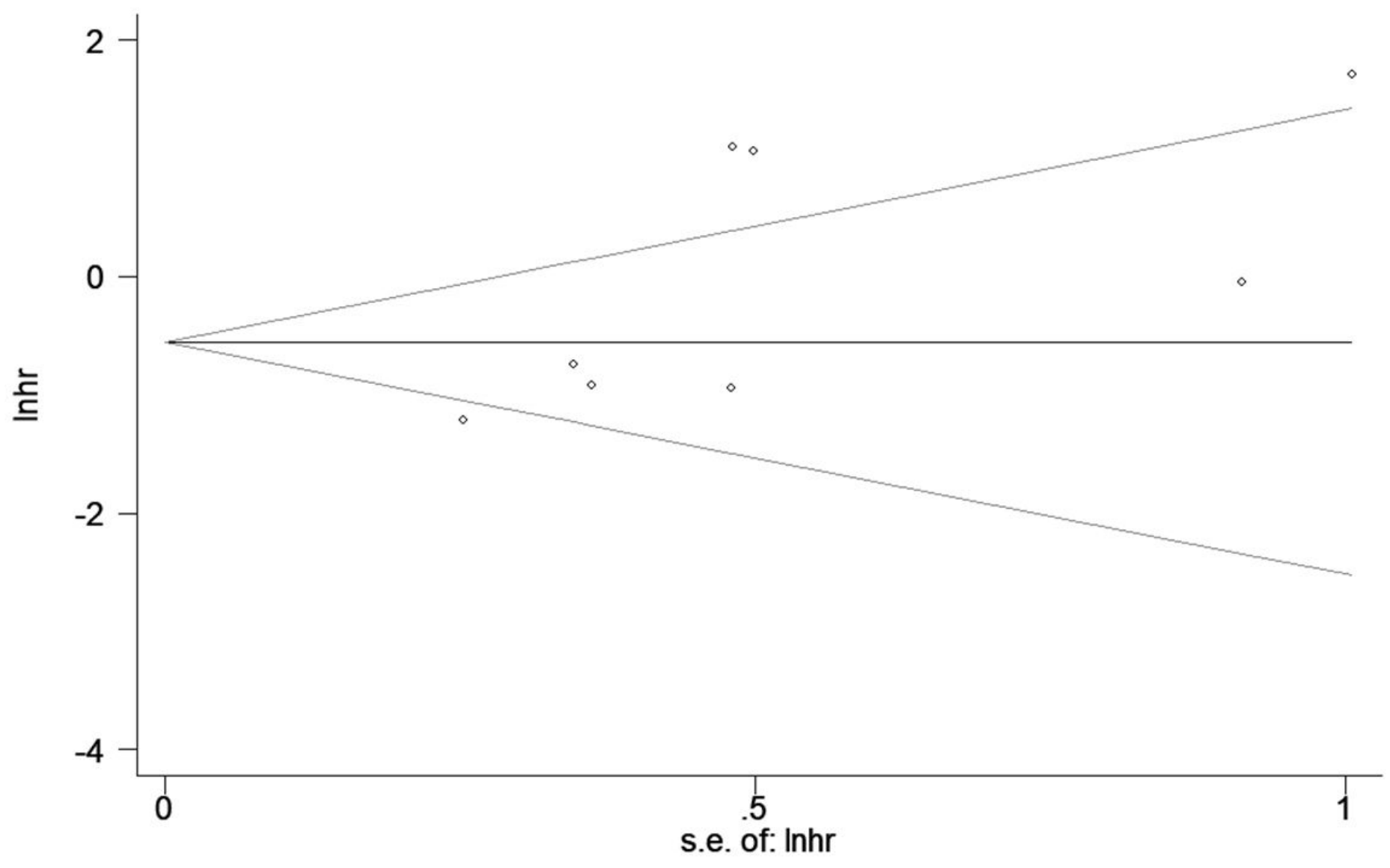

Figure 5

Sensitivity analysis of the association between maspin and overall survival 
Meta-analysis estimates, given named study is omitted

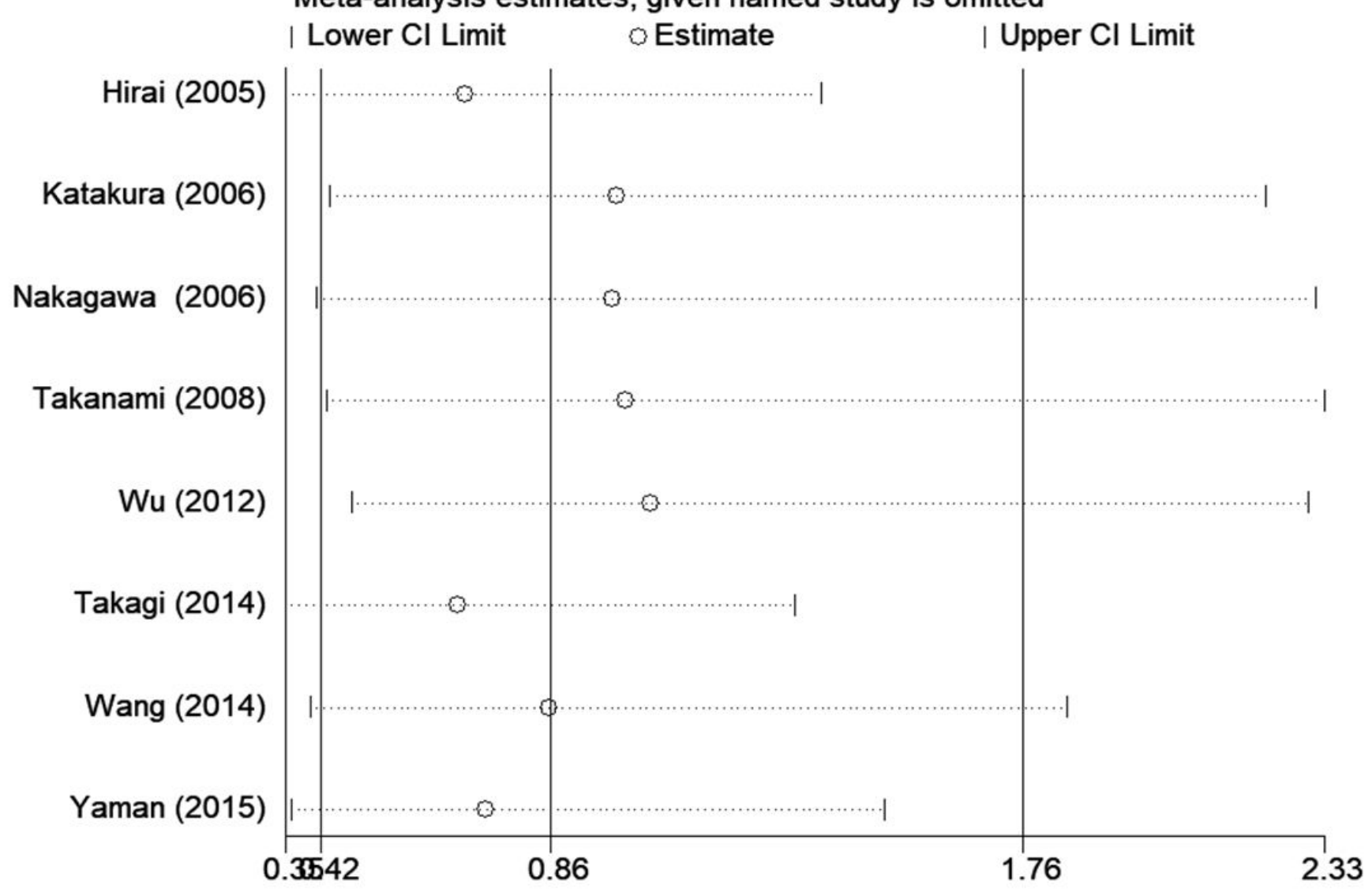

Figure 6

Begg's funnel plot of the association between maspin and overall survival. 